\title{
SEISMIC PERFORMANCE OF CROSS-SHAPED COLUMNS WITH 500 MPa GRADE REINFORCING STEEL BARS
}

\author{
Tie-cheng Wang, Xiao Liu, Hai-long Zhao
}

Original scientific paper Based on the experimental research on three cross-shaped columns with $500 \mathrm{MPa}$ grade reinforcing steel bars, the contrastive analysis is made on failure mode, bearing capacity and displacement ductility of each column specimens with different stirrup spacing under the identical axial compression ratio. The research shows that the longitudinal bars yield before spalling of core concrete and high-strength stirrups can provide significant confinement. Decreasing stirrup spacing can significantly improve the ductility of the specimens. Meanwhile, based on the fibre element in the OpenSees software, the mechanical characteristics of the specimens are stimulated using fined constitutive relation of materials. The test results are well consistent with the calculated results. The effects of the longitudinal bar strength, the stirrup strength and stirrup spacing on the mechanical performance of the specimens are investigated in this paper, and the results show that the decrease of the stirrup spacing and increase of the stirrup strength can significantly improve the bearing capacity, ultimate displacement and ductility of the specimens but has little effect on the yield displacement. The increase of the longitudinal bar strength can significantly increase the bearing capacity, yield displacement and ultimate displacement of specimens, but the displacement ductility factor will be decreased slightly.

Keywords: $500 \mathrm{MPa}$; cross-shaped column; displacement ductility; finite element; parameter analysis

\section{Seizmička performansa križnih stupova s armirnim čeličnim šipkama od $500 \mathrm{MPa}$}

Izvorni znanstveni članak

$\mathrm{Na}$ temelju eksperimentalnog istraživanja provedenog na tri križna stupa s armirnim čeličnim šipkama od $500 \mathrm{MPa}$, izvršena je kontrastivna analiza u odnosu na kvar, nosivost i duktilnost pomaka probnog uzorka svakog stupa s različitim razmakom metalnih spona uz identičan omjer aksijalnog stupnja kompresije. Istraživanje pokazuje da uzdužne šipke popuštaju prije raspadanja betonske jezgre, a da spone visoke čvrstoće mogu osigurati značajno oganičenje. Smanjenjem razmaka između spona može se znatno poboljšati duktilnost probnih uzoraka. U međuvremenu, na osnovu vlaknastog elementa u OpenSees softveru, stimuliraju se mehaničke karakteristike uzoraka poboljšanim odnosom sastavnih materijala. Rezultati ispitivanja dobro se slažu s rezultatima dobivenim proračunom. U radu su istraženi učinci čvrstoče uzdužne šipke, čvrstoče i razmaka spona na mehaničke karakteristike uzoraka, a rezultati pokazuju da se smanjenjem razmaka između spona i povećanjem čvrstoče spona može znatno poboljšati nosivost, krajnji pomak i duktilnost uzoraka, ali je učinak na pomicanje granice popuštanja malen. Povećanje čvrstoće uzdužne šipke može znatno povećati nosivost, pomicanje granice popuštanja i krajnji pomak uzoraka, ali će neznatno biti smanjen faktor duktilnosti pomaka.

Ključne riječi: $500 \mathrm{MPa}$; analiza parametara; duktilnost pomaka; finitni element; križni stup

\section{Introduction}

The use of high-strength reinforcement in concrete columns was first considered in the early 1930s [15] in a series of laboratory tests on columns with circular cross sections and spiral reinforcement, and the effect of high strength steel with yield strength up to $665 \mathrm{MPa}$ was studied. Later, the experimental work at PCA laboratories in the 1960s led to a series of reports titled "High-strength bars as concrete reinforcement", where concrete members reinforced with high strength steel with yield strength up to $828 \mathrm{MPa}$ were studied [4, 7, 13, 14]. Those experimental investigations focused on members under axial compression without or with small eccentricities, in which the longitudinal reinforcement was totally in compression. The study on seismic performance of members reinforced with high strength steel was only started 30 years ago. In Japan, series of concrete members with $600 \mathrm{MPa}$ grade steel bars were tested under displacement reversals by Otani et al. [11] and Ishikawa et al. [6]. Those tests provided the basis for employment of high strength steel as reinforcement in Japan. In the US, behaviour of MMFX steel, the innovative new high strength reinforcement characterized by high tensile strength and improved corrosion resistance was studied, focusing on seismic performance, shear behaviour and bond characteristics [3, 5, 9].

$500 \mathrm{MPa}$ steel bar is a type of newly adopted high strength reinforcing bar in China with nominal yield stress in excess of $500 \mathrm{MPa}$ and a fracture strain greater than conventional steel bars. The use of the kind of steel bars as reinforcement in concrete elements has the potential to reduce problems associated with congested reinforcement cages and concrete placement, as well as reduce costs associated with the shipment and placement of reinforcing steel. If the use of $500 \mathrm{MPa}$ bars as primary reinforcement is to be considered for practical use, the issues related to increased steel strain and crack control must be addressed: In spite of the high material strength, elastic modulus of the high strength reinforcement is almost the same with conventional reinforcement, oversize crack and ultimate deflection may occur due to the relatively high steel stress, threatening the serviceability of the structure. Concrete in compression primarily controls the failure of specimens with high strength reinforcement. If it crushes antecedent to the yield of the reinforcement, brittle failure will occur, resulting in underutilization of the reinforcement. These issues as well as the lack of experimental data regarding the seismic behaviour of concrete members reinforced with this type of material require further investigations on this topic.

In the multi-story and high-rise residential system, the application of the specially shaped concrete column has the following advantages: avoiding the prominent edges in the room, and providing convenience for the construction layout; increasing the usable floor area; in combination with the use of lightweight wall, the selfweight of the structure can be reduced. The cross-shaped 
column is the centre pillar of the specially shaped column structure. In comparison with the rectangular column, the specially shaped column has small and irregular section, so its mechanical property is complex, and the seismic performance is relatively poor, which restricts the applicable scope of the specially shaped column structure $[16,17]$. But with the application of $500 \mathrm{MPa}$ grade steel bars, the disadvantages of the specially shaped column will be modified to some extent, which will greatly enlarge the applicable scope of it. The benefits are even higher than in rectangular column structures. So it is necessary to conduct special research on the seismic performance of special-shaped column specimens.

The high-strength steel bars are defined here as steel bars with nominal yield stress larger than $500 \mathrm{MPa}$.

\section{Experimental Investigation \\ 2.1 Specimens design and material properties}

Three cross-shaped column specimens are designed in this test. The axial compression ratio of the specimens is $n=0,14$, and the stirrup spacing is $60 \mathrm{~mm}, 75 \mathrm{~mm}$ and $90 \mathrm{~mm}$ respectively, named $+60,+75$ and +90 specimens. The cross sections and facade designs of each column specimen are shown in Fig. 1. The designed height of each column is $1050 \mathrm{~mm}$. Design grade of the concrete strength of each specimen is C50 and the longitudinal bars and stirrups are made from $500 \mathrm{MPa}$ grade reinforcing steel bars. The size of the concrete specimens is: $150 \times 150 \times 150 \mathrm{~mm}$ for cubic tests and $150 \times 150 \times 300$ $\mathrm{mm}$ for prismatic tests, and three pieces of reinforcing steel were tested for each nominal diameter and average characteristic mechanical properties were calculated and then employed in the analytical approach.

Table 1 Material property of steel bars and concrete of the cross-shaped columns

\begin{tabular}{|c|c|c|c|c|c|c|c|}
\hline \multirow[b]{2}{*}{ Specimen } & \multicolumn{4}{|c|}{ Reinforcement } & \multicolumn{3}{|c|}{ Concrete } \\
\hline & Bar type & $\begin{array}{l}\text { Yield strength } \\
\qquad / \mathrm{MPa}\end{array}$ & $\begin{array}{l}\text { Ultimate } \\
\text { strength } \\
/ \mathrm{MPa}\end{array}$ & $\begin{array}{l}\text { Elastic modulus } \\
\qquad / 10^{5} \mathrm{MPa}\end{array}$ & $\begin{array}{c}\text { Cubic } \\
\text { compressive } \\
\text { strength / } \mathrm{MPa}\end{array}$ & $\begin{array}{c}\text { Prism } \\
\text { compressive } \\
\text { strength / } \mathrm{MPa}\end{array}$ & $\begin{array}{l}\text { Elastic modulus } \\
\qquad / 10^{4} \mathrm{MPa}\end{array}$ \\
\hline $\begin{array}{l}\text { Cross-shaped } \\
\text { column }\end{array}$ & $\begin{array}{c}500 \mathrm{D} 8 \\
500 \mathrm{D} 16\end{array}$ & $\begin{array}{l}519 \\
587\end{array}$ & $\begin{array}{l}800 \\
747\end{array}$ & $\begin{array}{l}2,01 \\
2,01\end{array}$ & 51,6 & 34,5 & 3,35 \\
\hline
\end{tabular}

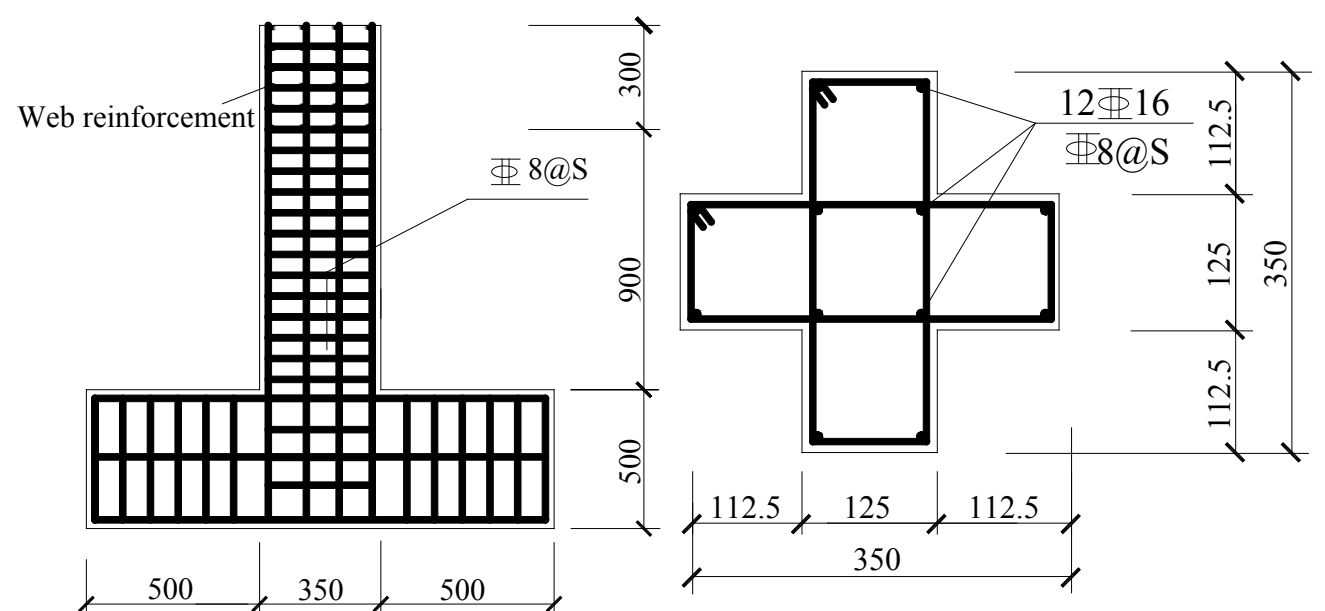

a) Elevation views

Note: S stands for stirrup spacing

b) Plan views

Figure 1 Section dimension and reinforcement details of cross-shaped columns

\subsection{Test setup, instrumentation and loading protocol}

In this test, the hydraulic jack is adopted to apply the vertical constant axial load to each specimen, while the horizontal load is applied to the end of the column by a bidirectional hydraulic actuator. The hydraulic jack was located between the reaction frame and the head of the column, and a roller was employed to keep the hydraulic jack moving together with the free end. To keep the axial load constant, a load cell was employed to monitor it and adjustment should be made if necessary. Load cells and LVDTs (linear variable differential transducer) are used to measure the horizontal load of the specimens and the horizontal displacement of the capital respectively. Moreover, the resistance strain gauge is used to measure the strain of the stirrup, longitudinal bar and concrete. The test setup is shown in Fig. 2a and the loading system is shown in Fig. 2b. Load-displacement mixed loading protocol is used in the specimen loading. There is one cycle for each level of target lateral load in the first procedure. The target load was started from $30 \mathrm{kN}$ with a level difference of $20 \mathrm{kN}$. The first procedure lasted until the specimen yielded (defined as one of the longitudinal bars yields, and the corresponding displacement of the specimen is the yield displacement.) and the displacement control procedure was started then. There were three cycles for each level of target lateral displacement in the displacement control procedure. The target lateral displacement was started from the yield displacement captured from the first procedure, with a level difference of the yield displacement. The second procedure lasts until the specimen failed (the specimen was defined to fail when the bearing capacity declines to $85 \%$ of the peak load.). The loading protocol details are shown in Fig. 3. 


\section{Test results}

\subsection{Failure mode}

With the increase of the load, the horizontal cracks appear in the front side of the web near the root of the column firstly, and then the flexure-shear crack appears on two sides of the web close to the root of the column; and the vertical cracks along with the longitudinal bars appear at the position of web and flange; finally, the concrete in the plastic zone of the web crushes and the specimens are damaged. The longitudinal bars of all specimens yield firstly, and then the crushed concrete causes the flexural failure. The failure mode is shown in Fig. 4. Despite different stirrup spacing, the failure mode is a typical flexural failure for each specimen, which is controlled by crushing of the concrete at the plastic zone near the bottom of the column. Rotations monitored by the inclinometers were very small, implying that the local discontinuous deformation could be ignored.

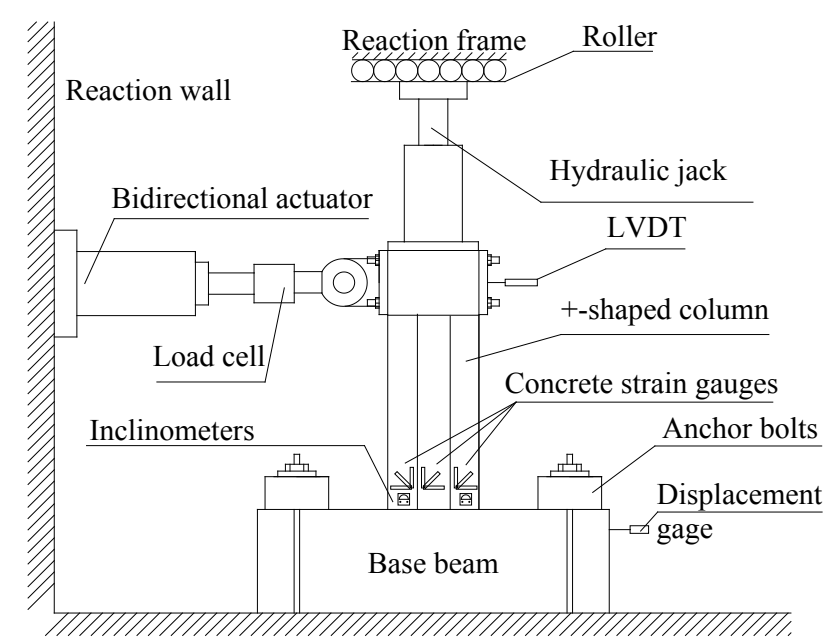

(a)

Figure 2 (a) Test setup and instrumentation; (b) Loading system

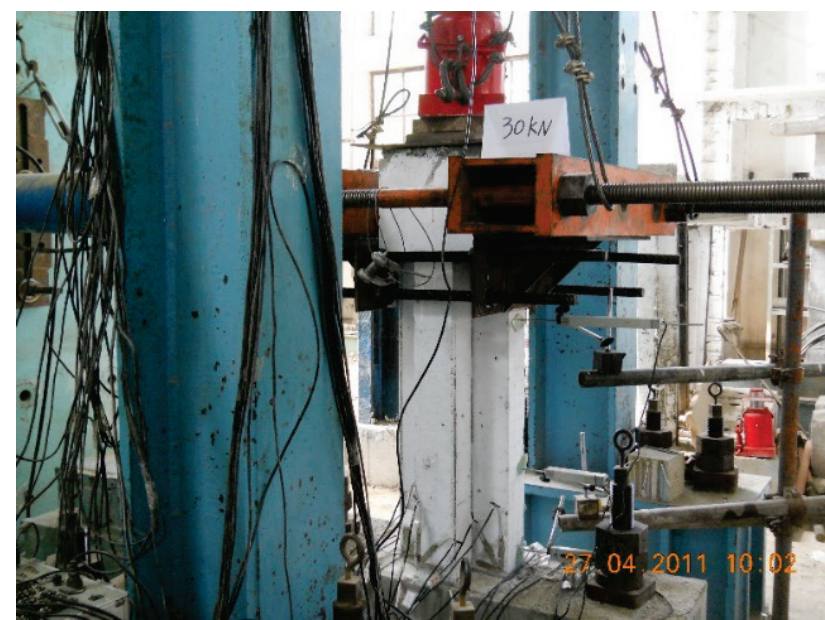

(b)

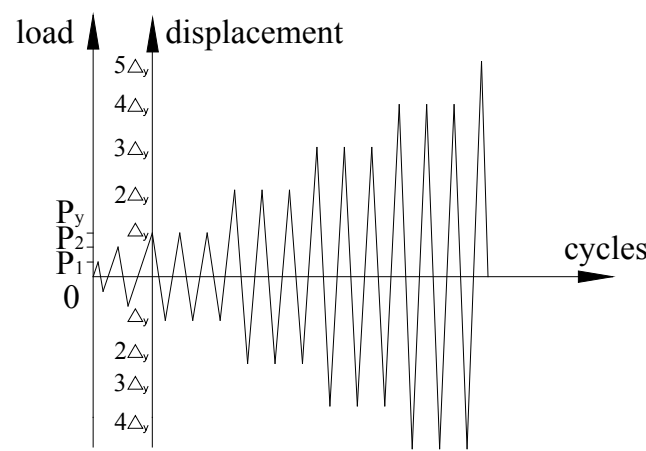

Figure 3 Loading protocol

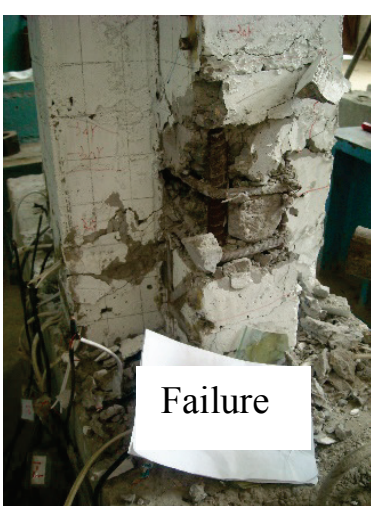

(a) +60

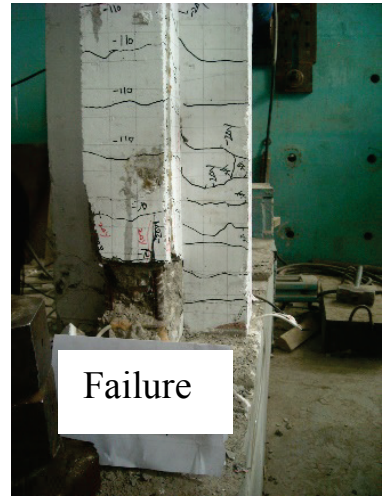

(b) +75

Several researches have shown that the application of the high-strength reinforcing steel bars will reduce the ductility of the specimens, but ductile flexural failure appears for three specimens in this paper which proves that the application of high-strength reinforcing steel bars will not cause brittle failure (the concrete crushes before the yield of the reinforcing steel bars).

Figure 4 Failure mode of cross-shaped columns

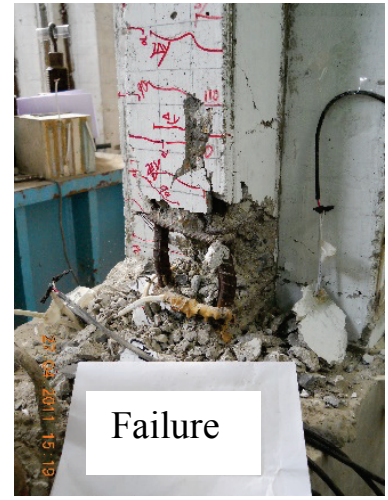

(c) +90

\subsection{Load-deflection behaviour}

The load-deflection behaviours of the cross-shaped specimen are shown in Fig. 5.

From the comparison of the curve of each specimen, it can be seen that the shapes of the curves are in relatively full spindle form, consistent with the typical flexural failure. The ultimate deflection of the specimen decreases with the increasing stirrup spacing. After the peak load, the bearing capacity of the specimens with larger stirrup spacing will deteriorate faster, showing that the stirrup spacing has a significant impact on the 
confinement of the core concrete, and decreasing stirrup spacing can reduce the cumulative damage of the specimen, so as to postpone the degradation of the bearing capacity.
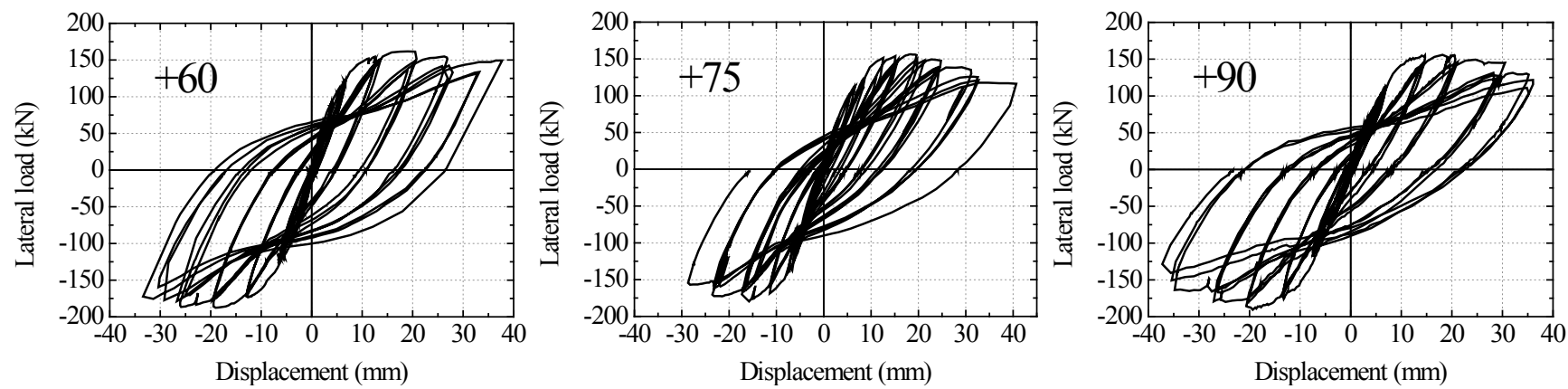

Figure 5 Load-deflection behaviours of the cross-shaped column

\subsection{Analysis of the bearing capacity and deformability}

The ductility of the specimen is usually measured by the displacement ductility factor, defined as:

$$
\mu_{\Delta}=\frac{\Delta_{\mathrm{u}}}{\Delta_{\mathrm{y}}} .
$$

In the formula, $\mu_{\Delta}$ is the displacement ductility factor; $\Delta_{\mathrm{u}}$ is the horizontal displacement at the top of column when being damaged (define the damage occurs when the load decreases to the $85 \%$ of the ultimate load), called the ultimate displacement; $\Delta_{\mathrm{y}}$ is the horizontal displacement at the top of the column when being yielded. The analysis results are shown in Tab. 2.

Table 2 Test results of cross-shaped columns

\begin{tabular}{|c|c|c|c|c|c|c|c|c|c|c|c|c|}
\hline \multirow{2}{*}{ Specimen } & \multicolumn{3}{|c|}{ Peak load / kN } & \multicolumn{3}{|c|}{ Yield displacement / mm } & \multicolumn{3}{|c|}{ Ultimate displacement / $\mathrm{mm}$} & \multicolumn{3}{|c|}{ Displacement ductility factor } \\
\hline & + & - & Avr. & + & - & Avr. & + & - & Avr. & + & - & Avr. \\
\hline+60 & 161,7 & 187,6 & 174,7 & 6,51 & 6,51 & 6,51 & 38,39 & 33,94 & 36,17 & 5,89 & 5,21 & 5,55 \\
\hline+75 & 156,2 & 179,7 & 167,9 & 6,34 & 6,26 & 6,30 & 32,74 & 28,24 & 30,49 & 5,16 & 4,51 & 4,84 \\
\hline+90 & 155,8 & 175,9 & 165,8 & 6,72 & 6,99 & 6,86 & 31,69 & 30,89 & 31,29 & 4,72 & 4,42 & 4,57 \\
\hline
\end{tabular}

Through the mutual comparison of each specimen, it can be seen that the bearing capacity of each specimen decreases slightly with the increasing stirrup spacing while the displacement ductility factor decreases significantly. The displacement ductility factor of +90 specimen is decreased by $25,0 \%$ and $9,3 \%$ respectively in comparison with that of +60 specimen and +75 specimen, showing that the stirrup spacing has a significant impact on the displacement ductility. The displacement ductility factor of each specimen is greater than 3 , consistent with a ductile failure mode, moreover, the concrete spalling occurs after the yield of the reinforcing steel bars. Therefore, $500 \mathrm{MPa}$ grade highstrength longitudinal bars can be fully used, and it is unnecessary to stipulate the upper limit of the design value for the longitudinal bar strength in the design.

\section{Finite element analysis \\ 4.1 Model establishment}

By force-based beam column element with fiber section in the open-source seismic analysis software OpenSees [12], specimens under horizontal low cyclic load and constant axial load are stimulated. The loading path which is consistent with the test loading protocol is used in the analysis. Concrete is stimulated by the simplified Chang and Mander [1, 18] model (named concrete 07 in OpenSees), considering the confinement effect of the transverse reinforcement on the core concrete. Reinforcing steel bars are stimulated by the model proposed by Kunnath S. K. [8] (named Reinforcing Steel Material in OpenSees). Degradation of the material performance under cyclic load is considered in these two materials.

\subsection{Confinement of the concrete}

Confined concrete model proposed by Mander [10] is adopted to calculate the confinement effect of the compound stirrup on the core concrete. The effective stirrup confined area of the cross-shaped section is shown in Fig. 6.

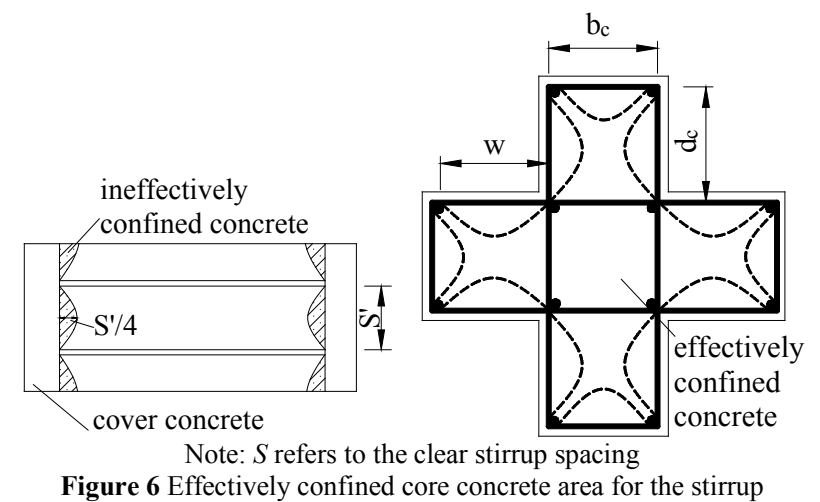

Mander's confinement concrete model can be adopted to any section shape, however, the specific calculation method of the cross-shaped section is not given. In this paper the effective confined coefficient of the cross-shaped section is deduced.

The effective confined coefficient $k_{\mathrm{e}}$ can be calculated according to the following formula: 
$k_{\mathrm{e}}=a_{\mathrm{s}} \cdot a_{\mathrm{n}}$,

where, $a_{\mathrm{s}}$ represents the effect of the stirrup spacing; $a_{\mathrm{n}}$ represents the effect of the stirrup type.

$$
\begin{aligned}
& a_{\mathrm{s}}=\frac{A_{\mathrm{es}}}{A_{\text {cor }}}=\frac{\left(b_{\mathrm{cor}}-\frac{s}{2}\right) \cdot\left(h_{\mathrm{cor}}-\frac{s}{2}\right)+\left(b_{\mathrm{fcor}}-b_{\mathrm{cor}}\right) \cdot\left(h_{\mathrm{fcor}}-\frac{s}{2}\right)}{A_{\text {cor }}}, \\
& A_{\text {cor }}=b_{\text {cor }} \cdot h_{\text {cor }}+\left(b_{\text {fcor }}-b_{\text {cor }}\right) \cdot h_{\text {fcor }}
\end{aligned}
$$

$a_{\mathrm{n}}=1-\frac{1}{6 A_{\text {cor }}} \sum_{i=1}^{n} l_{i}^{2}$,

where, $A_{\text {cor }}$ represents the area surrounded by the stirrup center line; $A_{\text {es }}$ represents the area of the strong confined region at the position of stirrup; $b_{\text {cor }}, h_{\text {cor }}, b_{\text {fcor }}, h_{\text {fcor }}$ are the geometric parameters of the section; as shown in Fig. 6, s refers to the clear stirrup spacing (calculated from the inner side of the stirrup). $l_{i}$ represents the clear spacing of the neighboring longitudinal bars.

After effective confined coefficients are obtained through calculation, the peak stress and peak strain of the confined concrete can be calculated according to the method proposed by Mander. The results of the three cross-shaped test columns are shown in Tab. 3.

Table 3 Material properties of confined concrete

\begin{tabular}{|l|c|c|}
\hline \multicolumn{1}{|c|}{ Type of concrete } & $f_{\mathrm{cc}}^{\prime} / \mathrm{MPa}$ & $\varepsilon_{\mathrm{cc}}$ \\
\hline $\begin{array}{l}\text { Confined concrete } \\
(60 \text { mm stirrup spacing) }\end{array}$ & 53,34 & 0,0058 \\
\hline $\begin{array}{l}\text { Confined concrete } \\
\text { (75 mm stirrup spacing) }\end{array}$ & 48,53 & 0,0049 \\
\hline $\begin{array}{l}\text { Confined concrete } \\
(90 \mathrm{~mm} \text { stirrup spacing) }\end{array}$ & 45,08 & 0,0042 \\
\hline
\end{tabular}

\subsection{Contrast between calculated and test results statement}

Contrast between calculated results and test results of the three specimens are shown in Fig. 7.

According to the contrast between the analytical curves and the test curves of the three specimens, based on the model simulated in this paper, the bearing capacity and yield displacement of the specimens as well as the strength and stiffness degradation under the cyclic load can get relatively reasonable simulation results. Meanwhile, this also shows that Mander confined concrete model is also applicable to the calculation of the cross-shaped columns.
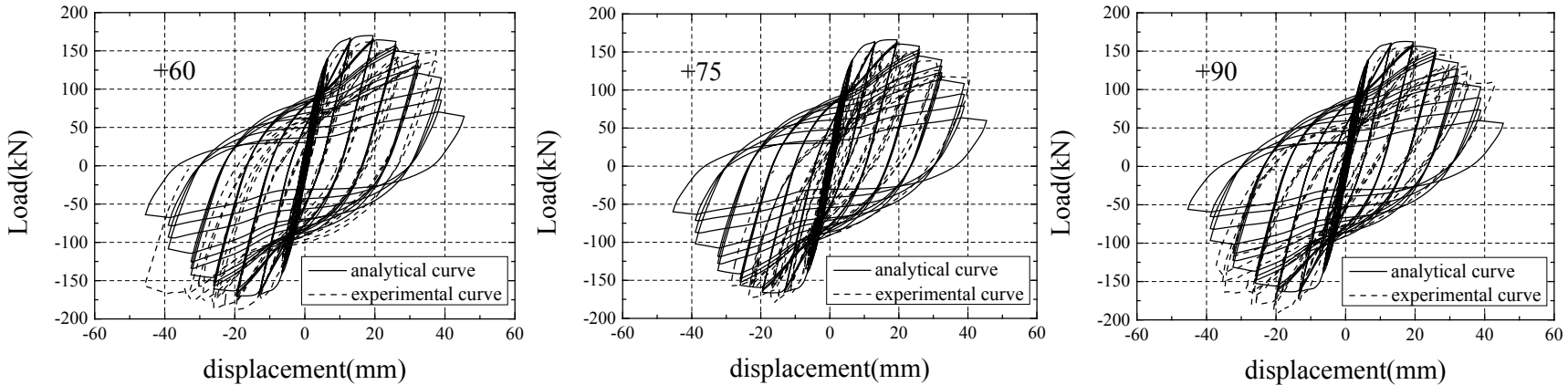

Figure 7 Contrast between the calculation curve and test curve

In Tab. 4, the test and calculated peak load, yield displacement, ultimate displacement and displacement ductility factor are compared. As the effect of the cyclic loading on the material performance is taken into account by the material model, the calculated results are basically consistent with the test results.

\begin{tabular}{|c|c|c|c|c|c|c|c|c|c|c|c|c|}
\hline \multirow{2}{*}{ Specimen } & \multicolumn{2}{|c|}{ Peak load / kN } & \multirow{2}{*}{$\frac{V_{\mathrm{C}}}{V_{\mathrm{E}}}$} & \multicolumn{2}{|c|}{$\Delta_{\mathrm{V}} / \mathrm{mm}$} & \multirow{2}{*}{$\frac{\Delta_{\mathrm{yC}}}{\Delta_{\mathrm{yE}}}$} & \multicolumn{2}{|c|}{$\Delta_{\mathrm{p}} / \mathrm{mm}$} & \multirow{2}{*}{$\frac{\Delta_{\mathrm{pC}}}{\Delta_{\mathrm{pE}}}$} & \multicolumn{2}{|c|}{$\Delta_{\mathrm{u}} / \mathrm{mm}$} & \multirow{2}{*}{$\frac{\Delta_{\mathrm{uC}}}{\Delta_{\mathrm{uE}}}$} \\
\hline & $V_{\mathrm{E}}$ & $V_{\mathrm{C}}$ & & $\Delta_{\mathrm{yE}}$ & $\Delta_{\mathrm{yC}}$ & & $\Delta_{\mathrm{pE}}$ & $\Delta_{\mathrm{pC}}$ & & $\Delta_{\mathrm{uE}}$ & $\Delta_{\mathrm{uC}}$ & \\
\hline+60 & 161,7 & 169,8 & 1,050 & 6,51 & 6,50 & 0,998 & 38,39 & 32,69 & 0,852 & 5,90 & 5,03 & 0,853 \\
\hline+75 & 156,2 & 165,8 & 1,061 & 6,34 & 6,49 & 1,024 & 32,74 & 31,79 & 0,971 & 5,16 & 4,90 & 0,950 \\
\hline+90 & 155,9 & 162,3 & 1,041 & 6,72 & 6,48 & 0,964 & 31,69 & 31,14 & 0,983 & 4,72 & 4,80 & 1,017 \\
\hline
\end{tabular}

Table 4 Contrast between the calculated results and test results

Note: Only the positive loading is taken into account. $\Delta_{\mathrm{y}}, \Delta_{\mathrm{p}}$ and $\Delta_{\mathrm{u}}$ are the displacements from the ultimate deflection point, peak load point and ultimate displacement point respectively. $V_{\mathrm{E}}$ and $V_{\mathrm{C}}$ are experimental and calculated lateral peak loads respectively.

\subsection{Parameter analysis}

Through the parameter analysis, the effect that the longitudinal bar strength, stirrup strength and the stirrup spacing have on the bearing capacity and ductility of specimens is studied. The $400 \mathrm{MPa}$ and $500 \mathrm{MPa}$ grades are selected as the strength of the longitudinal bars while the four grades, including 235, 300, 400 and $500 \mathrm{MPa}$, are selected as the stirrup strength. Four levels of spacing, including 60, 90, 120 and $150 \mathrm{~mm}$, are selected as the stirrup spacing. The axial compression ratio used for calculation is 0,14 , and the corresponding axial load is $350 \mathrm{kN}$. According to the stipulation of "Code for Concrete Structural Design" (GB 50010-2010), the standard values of yield strength and the ultimate strength are selected as the longitudinal bar strength. $400 \mathrm{MPa}$ is selected as the yield strength of $400 \mathrm{MPa}$ grade reinforcing steel bar, and $540 \mathrm{MPa}$ is selected as the ultimate strength; $500 \mathrm{MPa}$ is selected as the yield strength of $500 \mathrm{MPa}$ grade reinforcing steel bar, and 630 
$\mathrm{MPa}$ is selected as the ultimate strength. The material

model, as shown in Tab. 5 .

property of the confined concrete is calculated by Mander

Table 5 Material properties of confined concrete in parameter analysis

\begin{tabular}{|c|c|c|c|c|c|}
\hline Specimens & $\begin{array}{c}\text { Longitudinal bar } \\
\text { strength / MPa }\end{array}$ & Stirrup strength / MPa & Stirrup spacing / mm & Peak stress / MPa & Peak strain \\
\hline$+400-235-60$ & 400 & 235 & 60 & 43,92 & 0,004003 \\
\hline$+400-235-90$ & 400 & 235 & 90 & 39,57 & 0,003172 \\
\hline$+400-235-120$ & 400 & 235 & 120 & 37,31 & 0,002737 \\
\hline$+400-235-150$ & 400 & 235 & 150 & 35,93 & 0,002475 \\
\hline$+500-500-60$ & 500 & 500 & 60 & 52,76 & 0,005694 \\
\hline$+500-500-90$ & 500 & 500 & 90 & 44,73 & 0,004157 \\
\hline$+500-500-20$ & 500 & 500 & 120 & 40,28 & 0,003307 \\
\hline$+500-500-150$ & 500 & 500 & 150 & 37,51 & 0,002776 \\
\hline$+400-235-60$ & 400 & 235 & 60 & 43,92 & 0,004003 \\
\hline$+400-300-60$ & 400 & 300 & 60 & 46,24 & 0,004447 \\
\hline$+400-400-60$ & 400 & 400 & 60 & 49,61 & 0,00509 \\
\hline$+400-500-60$ & 400 & 500 & 60 & 52,76 & 0,005694 \\
\hline$+500-235-60$ & 500 & 235 & 60 & 43,92 & 0,004003 \\
\hline$+500-300-60$ & 500 & 300 & 60 & 46,24 & 0,004447 \\
\hline$+500-400-60$ & 500 & 400 & 60 & 49,61 & 0,005090 \\
\hline$+500-500-60$ & 500 & 500 & 60 & 52,76 & 0,005694 \\
\hline
\end{tabular}

\subsubsection{Effect of stirrup spacing}

The skeleton curves of the specimens in eight different cases are shown in Fig. 8a. All the specimens can be divided into two groups of specimens, including the specimen configured with $500 \mathrm{MPa}$ grade longitudinal bar and $500 \mathrm{MPa}$ grade stirrup, and the specimen configured with $400 \mathrm{MPa}$ grade longitudinal bar and 235 $\mathrm{MPa}$ grade stirrup. The specific design details of the specimens can be seen in Fig. 1. The high-strength reinforcing steel specimen and the conventional reinforcing steel specimen use the same longitudinal bar diameter. There are four different kinds of stirrup spacing in each group, while other design parameters are identical. The specific design parameters are shown in Tab. 5 and the contrast results of bearing capacity and ductility of all specimens are shown in Tab. 6.

Table 6 Performance of the specimens with different stirrup spacing

\begin{tabular}{|c|c|c|c|c|}
\hline Specimens & Peak load / kN & Yield displacement / mm & Ultimate displacement / mm & Displacement ductility factor \\
\hline$+400-235-60$ & 126,7 & 4,39 & 26,04 & 5,93 \\
\hline$+400-235-90$ & 122,1 & 4,38 & 24,93 & 5,69 \\
\hline$+400-235-120$ & 119,1 & 4,37 & 24,25 & 5,55 \\
\hline$+400-235-150$ & 116,6 & 4,36 & 23,74 & 5,44 \\
\hline$+500-500-60$ & 150,1 & 5,51 & 29,52 & 5,36 \\
\hline$+500-500-90$ & 143,1 & 5,5 & 28,47 & 5,18 \\
\hline$+500-500-120$ & 138,1 & 5,49 & 27,83 & 5,06 \\
\hline$+500-500-150$ & 133,6 & 5,47 & 27,33 & 4,99 \\
\hline
\end{tabular}

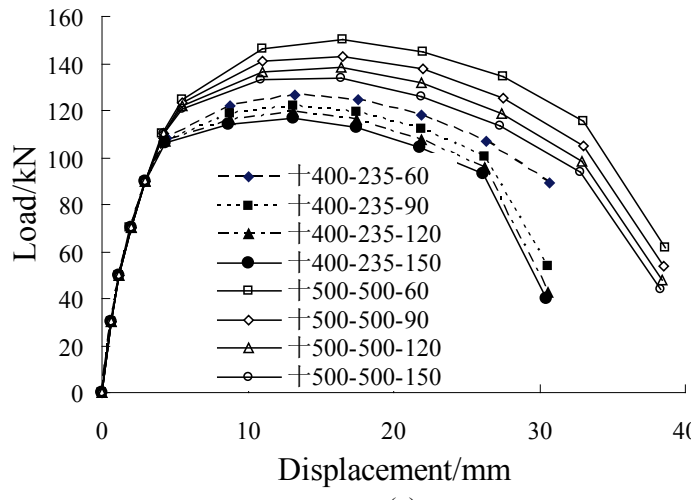

(a)

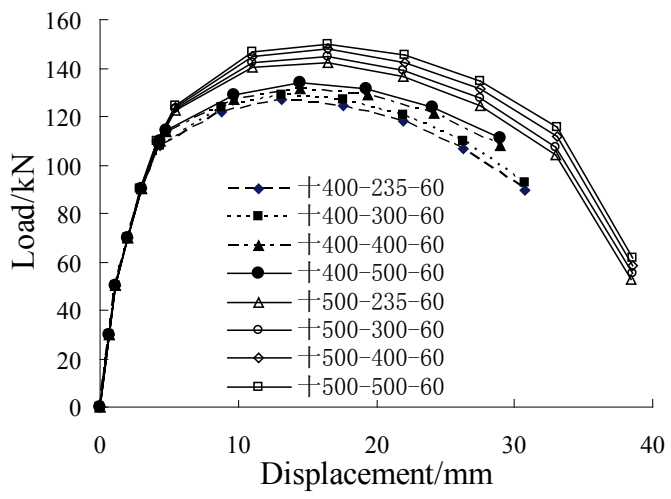

(b)

Figure 8 Effect of stirrup spacing (a) and effect of stirrup strength (b)

Through contrasting the specimens with the same longitudinal bar and stirrup configuration, it can be seen that the bearing capacity, ultimate displacement and the displacement ductility coefficient of the specimens significantly decrease with the increasing stirrup spacing; but the yield displacement basically remain unchanged. As for $500 \mathrm{MPa}$ longitudinal bar group, the poorest horizontal bearing capacity of the specimens with the 150 mm stirrup spacing decreases by $11,0 \%$ in comparison with the best horizontal bearing capacity of the specimens 
with $60 \mathrm{~mm}$ stirrup spacing; the ultimate displacement decreases by $7,4 \%$, and the displacement ductility coefficient decreases by $6,9 \%$. As for $400 \mathrm{MPa}$ longitudinal bar group, the poorest horizontal bearing capacity of the specimens with the $150 \mathrm{~mm}$ stirrup spacing decreases by $7,9 \%$ in comparison with the best horizontal bearing capacity of the specimens with $60 \mathrm{~mm}$ stirrup spacing; the ultimate displacement decreases by $8,8 \%$, and the displacement ductility coefficient decreases by $8,3 \%$. Through contrasting with the specimens with the same stirrup spacing and different reinforcing steel strength, it can be seen that the bearing capacity, yield displacement and ultimate displacement of the high-strength reinforcing steel specimens are significantly higher than that of the low-strength reinforcing steel specimens, and the displacement ductility coefficient declines slightly. Among them, the bearing capacity increases by $14,6 \% \div 18,5 \%$, the yield displacement increases by about $25 \%$, the ultimate displacement increases by $13,4 \% \div 15,1 \%$, and the displacement ductility factor decreases by $8,3 \% \div 9,6 \%$.

Table 7 Performance of the specimens with different stirrup spacing

\begin{tabular}{|c|c|c|c|c|}
\hline Specimens & Ultimate load / kN & Yield displacement / mm & Ultimate displacement / mm & Displacement ductility factor \\
\hline$+400-235-60$ & 126,8 & 4,4 & 26,04 & 26,64 \\
\hline$+400-300-60$ & 128,7 & 4,39 & 29,81 & 6,92 \\
\hline$+400-400-60$ & 131,6 & 4,84 & 30,73 & 6,07 \\
\hline$+400-500-60$ & 133,9 & 4,83 & 28,34 & 6,36 \\
\hline$+500-235-60$ & 142,3 & 5,16 & 28,70 & 5,49 \\
\hline$+500-300-60$ & 144,6 & 5,22 & 5,16 & 29,52 \\
\hline$+500-400-60$ & 147,6 & 5,29 & 5,50 & 5,51 \\
\hline$+500-500-60$ & 150,1 & 5,36 & 5 \\
\hline
\end{tabular}

\subsubsection{Effect of stirrup strength}

The skeleton curves of the specimens on eight different cases are shown in Fig. 8b, all the specimens can be divided into two groups of specimens, including the specimen configured with $400 \mathrm{MPa}$ grade longitudinal bar. The high-strength reinforcing steel specimens and the conventional reinforcing steel specimens use the same longitudinal bar diameter, and the specific design details can be seen in Fig. 1. $60 \mathrm{~mm}$ of stirrup spacing is selected for the specimens. There are four different kinds of stirrup spacing in each group, and other design parameters are identical. The specific design parameters are shown in Tab. 5 and the contrast results of bearing capacity and ductility of these specimens are shown in Tab. 7.

Through contrasting the specimens with the same longitudinal bar and stirrup configuration, it can be seen that the bearing capacity, ultimate displacement and the displacement ductility factor of the specimens significantly increase with the increasing stirrup strength. As for $500 \mathrm{MPa}$ longitudinal bar group, the best horizontal bearing capacity of the specimens with 500 MPa stirrup strength increases by 5,5\% in comparison with the worst horizontal bearing capacity of the specimens with $235 \mathrm{MPa}$ stirrup strength; the ultimate displacement increases by $4,2 \%$, and the displacement ductility factor basically remains unchanged. As for 400 MPa longitudinal bar group, the best horizontal bearing capacity of the specimens with $500 \mathrm{MPa}$ stirrup strength increases by $5,7 \%$ in comparison with the worst horizontal bearing capacity of the specimens with 235 MPa stirrup strength; the ultimate displacement increases by $18,1 \%$, and the displacement ductility factor increases by $7,4 \%$. It can be seen from the above comparison that the effects on the performance of the specimens configured with high-strength reinforcing steel bar based on increasing the stirrup strength is less significant than that of the specimens with low-strength reinforcing steel.

Comparing the decrease of the stirrup spacing with the increases of the stirrup strength, the former will increase more the bearing capacity and ductility of the cross-shaped column, so this way is more economic and effective. The yield displacement and ultimate displacement of the specimens configured with highstrength reinforcing steel bars are larger than those of the specimens configured with conventional reinforcing steel bars, and the deformability is better. However, the yield displacement seems to increase more rapidly than the ultimate displacement, manifested as the slight decrease of the displacement ductility factor.

\section{Conclusion}

Based on the research and finite element analysis on the low cyclic load test of the cross-shaped column with $500 \mathrm{MPa}$ grade reinforcing steel bar, the conclusions are drawn as belows:

Flexural failure occurs in all the cross-shaped column specimens, and the high-strength reinforcing steel bars will yield before the concrete crushes. The high-strength stirrups can significantly confine the concrete in core area, and improve the ductility of the specimens. Decreasing stirrup spacing can improve the ductility and reduce the cumulative damage.

By virtue of the confined concrete model proposed by Mander, the performance of the core concrete in crossshaped column specimens with $500 \mathrm{MPa}$ grade reinforcing steel bars can be simulated reasonably. Based on the model established by OpenSees software in this paper, the mechanical properties of all cross-shaped specimens under low cyclic load can be simulated reasonably.

The increase of the stirrup strength and decrease of the stirrup spacing can significantly improve the bearing capacity, ultimate displacement and displacement ductility factor of the specimens, but have less effect on the yield displacement. Relative to the increase of the stirrup strength, the decrease of stirrup spacing is a more effective measure to improve the specimen performance. The bearing capacity, yield displacement and ultimate 
displacement of the specimens configured with $500 \mathrm{MPa}$ longitudinal bars are greater than those of the specimens configured with $400 \mathrm{MPa}$ longitudinal bars, but the displacement ductility factor is relatively smaller.

\section{Acknowledgement}

The subject was supported by the Research Fund for the Doctoral Program of Higher Education of China (No. 20120032120055).

\section{References}

[1] Chang, G. A.; Mander, J. B. Seismic energy based fatigue damage analysis of bridge columns: Part I - Evaluation of seismic capacity, National Center for Earthquake Engineering Research, Buffalo, N.Y., 1994.

[2] Dhakal, R.; Maekawa, K. Modeling for postyield buckling of reinforcement. // J. Struct. Eng., ASCE. 128(2002), pp. 1139-1147. DOI: 10.1061/(ASCE)0733-9445(2002)128:9(1139)

[3] El-Hacha, R.; El-Agroudy, H.; Rizkalla, S. H. Bond characteristics of high-strength steel reinforcement. // ACI Struct. J. 103, 6(2006), pp. 771-783.

[4] Hognestad, E. High strength bars as concrete reinforcement, Part 1 - Introduction to a series of experimental reports. // J. PCA. Res. Develop. Lab. 3, 3(1961), pp. 23-29.

[5] Hassan, T. K.; Seliem, H. M.; Dwairi, H.; Rizkalla, S. H.; $\mathrm{Zia}, \mathrm{P}$. Shear behavior of large concrete beams reinforced with high-strength steel. // ACI Struct. J. 105, 2(2008), pp. 173.

[6] Ishikawa, Y.; Kimura, H.; Ueda, T.; Abe, H. Seismic Structural Performance of R/C Beam-Column Joints with High-Strength Steel Bars. // Takenaka Technical Research Report No. 64, Takenaka Corporation, Osaka, Japan, 2008.

[7] Kaar, P. H.; Hognestad, E. High strength bars as concrete reinforcement, Part 7- Control of cracking in T-Beam flanges. // J. PCA. Res. Develop. Lab. 7, 1(1965), pp. 4253.

[8] Kunnath, S. K.; Heo, Y.; Mohle, J. F. Nonlinear uniaxial material model for reinforcing steel bars. // J. Struct. Eng. ASCE. 4(2009), pp. 333-343. DOI: 10.1061/(ASCE)07339445(2009)135:4(333)

[9] Lepage, A.; Tavallali, H.; Pujol, S.; Rautenberg, J. HighPerformance Steel Bars and Fibers as Concrete Reinforcement for Seismic-Resistant Frames. // Advances in Civil Engineering Journal, Hindawi Publishing Corporation, Volume 2012, Article ID 450981, 13 pp.

[10] Mander, J. B.; Priestley, M. J. N.; Park, R. Theoretical stress-strain model for confined concrete. // J. Struct. Eng., ASCE. $\quad 114, \quad 8(1988), \quad$ pp. 1804-1826. DOl: 10.1061/(ASCE)0733-9445(1988)114:8(1804)

[11] Otani, S.; Nagai, S.; Aoyama, H. Load-Deformation Relationship of High-Strength Reinforced Concrete Beams. // Mete A. Sozen Symposium: a Tribute from his Students, SP-162, J. K. Wight, editor, American Concrete Institute, Farmington Hills, MI, pp. 35-52, 1996.

[12] OpenSees. Open system for earthquake engineering simulation. // Open source software. URL: http://opensees.berkeley.edu. (2008)

[13] Pfister, J. F.; Mattock, A. H. High strength bars as concrete reinforcement, Part 5 - Lapped splices in concentrically loaded columns. // J. PCA. Res. Develop. Lab. 5, 2(1963), pp. 27-40.

[14] Pfister, J. F.; Hognestad, E. High strength bars as concrete reinforcement, Part 6 - Fatigue tests. // J. PCA. Res. Develop. Lab. 6, 1(1964), pp. 65-84.
[15] Richart, F. E.; Brown, R. L. An investigation of reinforced concrete columns. // Bulletin No. 267. Urbana (IL): Univ. of Illinois Engineering Experiment Station, 1934.

[16] Wang, T. C.; Zhang, X. H.; Kang, G. Y. Experimental comparison of seismic behavior of two RC frames with specially shaped columns. // Trans. Tianjin Univ. 40, 7(2007), pp. 791-798 (in Chinese).

[17] Wang, T. C.; Lin, H.; Kang, G. Y. Experiment and nonlinear static analysis of RC special shaped column frames. // Trans. Tianjin Univ. 39, 12(2006), pp. 1457-1464 (in Chinese).

[18] Waugh, J. D. Nonlinear Analysis of T-Shaped Concrete Walls Subjecteded to Multi-Directional Displacements. $\mathrm{PhD}$ Diss., United States - Iowa: Iowa State University, 2009.

\section{Authors' addresses}

Tie-cheng Wang, prof. PhD

School of Civil Engineering

Key Laboratory of Coast Civil Structure Safety of the Ministry of Education, Tianjin University

300072 Tianjin, China

\section{Xiao Liu, PhD candidate}

School of Civil Engineering, Tianjin University

300072 Tianjin, China

E-mail: tumuliuxiao@163.com

Hai-long Zhao, Lecturer, PhD (corresponding author) School of Civil Engineering

Key Laboratory of Coast Civil Structure Safety of the Ministry of Education, Tianjin University 300072 Tianjin, China 